\title{
Characteristics of Aerosol Size Distributions and New Particle Formation Events at Delhi: An Urban Location in the Indo-Gangetic Plains
}

OPEN ACCESS

Edited by:

Falguni Patadia,

Universities Space Research Association (USRA), United States

Reviewed by:

Bijoy Vengasseril Thampi, Science Systems and Applications,

Inc., United States

Jean-Baptiste Renard, UMR7328 Laboratoire de physique et chimie de l'environnement et de

l'Espace (LPC2E), France

*Correspondence: Sachchidanand Singh ssingh@nplindia.org

Specialty section: This article was submitted to Atmospheric Science, a section of the journal Frontiers in Earth Science

Received: 30 July 2021 Accepted: 08 November 2021 Published: 07 December 2021

Citation:

Jose S, Mishra AK, Lodhi NK, Sharma SK and Singh S (2021) Characteristics of Aerosol Size Distributions and New Particle Formation Events at Delhi: An Urban Location in the Indo-Gangetic Plains.

Front. Earth Sci. 9:750111. doi: 10.3389/feart.2021.750111

\section{Sandhya Jose ${ }^{1,2}$, Amit Kumar Mishra ${ }^{3}$, Neelesh K. Lodhi ${ }^{4}$, Sudhir Kumar Sharma ${ }^{1,2}$ and Sachchidanand Singh ${ }^{1,2 *}$}

${ }^{1}$ Environmental Sciences and Biomedical Metrology Division, CSIR-National Physical Laboratory, New Delhi, India, ${ }^{2}$ Academy of Scientific and Innovative Research (AcSIR), Ghaziabad, India, ${ }^{3}$ School of Environmental Sciences, Jawaharlal Nehru University, New Delhi, India, ${ }^{4}$ Centre for Environment Science and Climate Resilient Agriculture (CESCRA), ICAR-Indian Agricultural Research Institute, New Delhi, India

Accurate information about aerosol particle size distribution and its variation under different meteorological conditions are essential for reducing uncertainties related to aerosol-cloudclimate interaction processes. New particle formation (NPF) and the coagulation significantly affect the aerosol size distribution. Here we study the monthly and seasonal variability of aerosol particle size distribution at Delhi from December 2011 to January 2013. Analysis of aerosol particle size distribution using WRAS-GRIMM reveals that aerosol particle number concentration is highest during the post monsoon season owing to the effect of transported crop residue and biomass burning aerosols. Diurnal variations in number concentration show a bimodal pattern with two Aitken mode peaks in all the seasons. Monthly volume size distribution also shows bi-modal distribution with distinct coarse and fine modes. NPF events are observed less frequently in Delhi. Out of 222 days of WRAS data, only 17 NPF events have been observed, with higher NPF frequency during summer season. Growth rate of the nucleation mode of NPF events vary in the range $1.88-21.66 \mathrm{~nm} / \mathrm{h}$ with a mean value of $\sim 8.45 \pm 5.73 \mathrm{~nm} / \mathrm{h}$. It is found that during NPF events the Aitken and nucleation mode particles contribute more to the number concentration. Simultaneous measurement of UV flux and particulate matter $\left(\mathrm{PM}_{10}\right.$ and $\left.\mathrm{PM}_{2.5}\right)$ have also been done along with particle number size distribution measurement to understand the possible mechanisms for NPF events over the study location.

Keywords: aerosol size distribution, nucleation, Aitken mode, new particle formation, particle growth rate

\section{INTRODUCTION}

The size distribution of atmospheric aerosol particles are known to have plausible effects on radiation budget through direct interaction (Warner and Twomey, 1967; Liou, 1992; Andreae et al., 2004; Dusek et al., 2006); cloud characteristics by affecting cloud condensation nuclei, CCN (Ramanathan et al., 2001; Andreae et al., 2004) and droplet number density (Rosenfeld et al., 2008; Zhang et al., 2011); visibility (Hand et al., 2002; Bäumer et al., 2008; Singh and Beegum, 2013); communication (Ricklin et al., 2006); human health (Harrison, and Yin, 2000; Valavanidis et al., 2008) and 
agriculture (Chameides et al., 1999). Although, the climatic and human health implications of aerosol have drawn great attentions in the last 2 decades (Lighty et al., 2000; Bergin et al., 2001; Singh and Dey, 2012; Boucher et al., 2013; Gogoi et al., 2021), there are still scarcity of high-resolution (both spatial and temporal) data on aerosol particle size distribution at distinct geographic parts of the world. Geographical and seasonal differences significantly influence the aerosol particle size distribution (Kompalli et al., 2014). Especially, over the highly heterogeneous geographic regions of South Asia, accurate and improved understanding of aerosol size distribution is highly essential to understand distinct sources, transformation and growth processes of aerosols.

While primary sources are dominant contributors to the abundance of atmospheric aerosols, secondary aerosol production is unique in altering aerosol size distribution pattern, thus changing their dynamical properties. Depending on the abundance of precursor gases, solar radiation and preexisting particle concentrations (Kulmala et al., 2001; Ueda et al., 2016), gas to particle conversion (i.e., new particle formation NPF) occurs leading to the formation of secondary aerosols (Kulmala et al., 2004; Dal Maso et al., 2005; Seinfeld and Pandis, 2016). Meteorology and the boundary layer dynamics also impact the NPF events frequency and formation mechanism (Kuang et al., 2010; Wehner et al., 2010). NPF events are mostly reported during day time, mainly related to the photochemistry formation theory (Kuang et al., 2008; Metzger et al., 2010). Sulphuric acid is considered as one of the main contributor to the NPF events, which in turn is produced by the photooxidation of sulphur dioxide and $\mathrm{OH}$ radicals (Lee et al., 2019). Recent study by Jokinen et al. (2017) showed the significance of photochemistry in NPF, by depicting the decrease in UV radiation followed by the decrease in concentration of $\mathrm{H}_{2} \mathrm{SO}_{4}$ and nitrogen containing highly oxidized compounds during a partial solar eclipse, resulting in the inhibition of NPF events over the study site.

Delhi has a population of more than 1 million (Statistical Abstract of Delhi-2014) and has a large number of daily traffic on the roads. Two coal power plants (Rajghat and Badarpur) in the vicinity and the heavy industrial activities and high traffic intrusion account for the increased pollution events in Delhi (Chowdhury et al., 2017). The city, which comes under the IndoGangetic Plains (IGP), has a unique geographical and meteorological conditions. The IGP alluvial plains, the Thar Desert and the Aravalli Hills surround Delhi in north and west respectively and accounts for this uniqueness. Delhi encounters dust storm events during April-June and biomass burning events during the October-November months (Singh et al., 2005; Singh et al., 2010; Mishra and Shibata, 2012; Lodhi et al., 2013; Mishra et al., 2014).

Owing to the highly polluted scenario, a number of studies have been done on aerosol size distribution and NPF in Delhi (Mönkkönen et al., 2005; Sarangi et al., 2015; Pant et al., 2016). Increased concentration of $\mathrm{PM}_{10}$ and $\mathrm{PM}_{2.5}$ particles are reported over Delhi during winter and post monsoon season (Mukherjee et al., 2018; Bhandari et al., 2020). Apart from particulate matters, gas species such as nitrates and sulphates are also reported in high concentration over the study location (Bhandari et al., 2020) making conducive environment for chemical transformation and new particle formation events over Delhi. However, a systematic seasonal analysis of aerosol particle size distribution and NPF events are scarce over the region. The main aim of this paper is to recognize the monthly and seasonal variation in the number concentration and size distribution of the aerosol particles and see how the particle modes vary over the span of a year. Also, we present here the analysis on observed nucleation events during the time period. Important parameters related to NPF events such as growth rate and condensation sink have also been estimated during different seasons. This study also tries to enumerate some of the factors contributing to the observed NPF events during summer and winter season.

\section{DATA AND METHODOLOGY}

\section{Measurement Site and Instrumentation}

The aerosol particle size distribution measurements are carried out using Wide Range Aerosol Spectrometer (WRAS) located at CSIR-National Physical Laboratory (CSIR-NPL), Delhi $\left(28.64^{\circ} \mathrm{N}\right.$, $\left.77.17^{\circ} \mathrm{E}\right)$ during December 2011 to January 2013. The system comprises of a Scanning Mobility Particle (SMPS + C) and an Optical Particle Counter (OPC). The GRIMM SMPS + C system consists of a high resolution condensation particle counter (CPC) attached to the GRIMM "Vienna Type" M-DMA (Monodisperse Differential Mobility Analyser). DMA classifies the particles according to its electrical mobility which is then measured using a CPC. Both components together measure in the ultrafine size range from 5 to $350 \mathrm{~nm}$. OPC which work on the light scattering technology for particle counting gives the particle size distribution in 31 channels ranging from $250 \mathrm{~nm}$ to $32 \mu \mathrm{m}$ (Grimm and Eatough, 2009). Semiconductor laser serves as the light source for OPC. Thus integrating both, SMPS $+\mathrm{C}$ and OPC data using a GRIMM software, the WRAS system gives the particle size distribution in 72 channel ranging from $5.5 \mathrm{~nm}$ to $32 \mu \mathrm{m}$. There is an overlapping region from 250 to $350 \mathrm{~nm}$ due to the integration of SMPS and OPC, here we take the average number concentration for the analysis. A Nafion dryer is used inside the sampling probe in order to avoid the loss of volatile components and dehumidify the sample during the measurement period. The GRIMM-WRAS data is supposed to have an uncertainty in total flow rate up to $5 \%$ as per manufacturer specification. SMPS is reported to have an uncertainty of less than $10 \%$ for particles in the size range of $20-200 \mathrm{~nm}$, while for particles above and below this range uncertainty increases (Wiedensohler et al., 2012). Uncertainty of OPC is estimated to be about 9.9\% (Grimm and Eatough, 2009). The detailed description and principle of the instrument are discussed elsewhere (Grimm and Eatough, 2009). The system also has an integrated meteorological sensor which provides temperature, relative humidity and wind vector data.

The incoming global (direct + diffused) solar radiation were measured on a horizontal surface in the UV (280-400 nm) range using the Kipp \& Zonen CUV-4 radiometer respectively. The radiation flux measurements have an estimated experimental error of $3 \%$ in the shortwave and $<10 \%$ in the UV range. 
More details about the radiation flux measurements are reported elsewhere (Bano et al., 2013). Ambient $\mathrm{SO}_{2}$ data is obtained using the self-calibrated Horiba APSA-370 $\mathrm{SO}_{2}$ analyzer which uses Ultraviolet Fluorescence (UVF) method as the operating principle for measurements. The detailed working principle is reported elsewhere (Suneja et al., 2019).

Continuous sampling was done from December 2011 to January 2013, however, some data gaps exist on a few occasions whenever technical errors were encountered during the observation. A total of 222 days' data has been studied and analyzed seasonally, categorized as, winter (DJF), summer (MAMJ), monsoon (JAS) and post monsoon (ON). Considering the regional climatic conditions June has been grouped into summer as south west monsoon hits Delhi by the end of June or early July. The instrument provides aerosol particle size distribution at a span of $5 \mathrm{~min}$ interval. Percentage data availability for winter, summer, monsoon and postmonsoon are $\sim 36 \%, \sim 49 \%, \sim 35$ and $\sim 63 \%$ of the total days respectively. The solar flux data was obtained in $\mathrm{Wm}^{-2}$ every 2 min, during the observation period and averaged hourly and seasonally.

\section{Identifying NPF Events}

During the preliminary stages of the analyses the data has been flagged and removed if any discrepancy in the instrument or measurement is noted. Out of the entire experimental period, a total of 222 days of data has been found proper and the same has been used for further analysis. NPF events have been identified from the collected data sets based on the following criteria, as also suggested by (Dal Maso et al., 2005): 1) A distinctly new mode of particles must appear in the size distribution; 2) the mode must start in the nucleation mode; 3 ) the mode must prevail over a time span of few hours; 4) the new mode must show signs of growth. Further, the NPF events have been identified according to the following scrutiny techniques. 1) The visual identification of the contour plots of particle size distribution over the $24 \mathrm{~h}$ period. 2) The variation of mode diameter across $24 \mathrm{~h}$ period. 3) Individual mode analysis of the size distribution at each 5 min interval.

In this study, we have classified the modes into three categories, Nucleation mode $(5-30 \mathrm{~nm})$, Aitken mode $(30-100 \mathrm{~nm})$ and accumulation mode $(100-1,000 \mathrm{~nm})$ (Ueda et al., 2016). The data has been classified into event days, nonevent days, and unidentified event days according to a number of criteria discussed in various peer reviewed papers (Dal Maso et al., 2005; Kanawade et al., 2014; Kamra et al., 2015; Tröstl et al., 2016). Based on this, three categories of events (classifications) emerge with their distinct features. First, 1) NPF Event days, which are those days in which there is a sudden outburst of number concentration in the size range between 5 and $30 \mathrm{~nm}$ for a prolonged time period of 2-3 h (Kanawade et al., 2014). Another category, 2) Non Event days are those for which no nucleation and particle growth is observed in these days. The contour plots show no particular trend or variations in the number concentration. Finally, third category 3) Unidentified events days are the ones where we are unable to deduce the features of the number concentration from the contour plot and other scrutiny methods due to high level of noises in the data or the gaps in the data. This can be due to the background pollution and the haze conditions prevailing in the atmosphere.

\section{Growth Rate Calculations}

The rate of change of diameter of the particle $\left(\mathrm{dD}_{\mathrm{p}} / \mathrm{dt}\right)$ is termed as growth rate (GR), where $D_{p}$ is the diameter of the particle and $t$ is time (Tröstl et al., 2016). The growth rate can be found out from the linear regression analysis of the mode diameter $\left(D_{p}\right)$ with time (Tröstl et al., 2016; Salimi et al., 2017). The slope of the regression gives the growth rate. The linear regression equation is given by

$$
D p=a_{0}+a_{1} t
$$

where $\mathrm{a}_{0}$ is the intersect at the $y$ axis and $\mathrm{a}_{1}$ is the slope of the line pointing to the growth rate.

\section{Condensation Sink}

Condensation sink (CS) is the scavenging speed of the gaseous molecule due to the condensation onto particles. It mainly depends on the particle size and the condensation (Ueda et al., 2016), and the equation is given by Kulmala et al. (2001) as

$$
C S=2 \pi D_{v} \sum_{i} D_{P, i} \beta_{m, i} N_{i}
$$

$D_{v}$ is the diffusion coefficient of $\mathrm{H}_{2} \mathrm{SO}_{4}$ and is assigned as $0.104 \mathrm{~cm}^{2} \mathrm{~s}^{-1}$ (Kanawade et al., 2014). $D_{P, i}$ and $N_{i}$ is the center particle diameter and number concentration of the size class $i$ respectively. $\beta_{m, i}$ denotes the size dependent transition correction factor given by Fuchs and Sutugin (1971) and is expressed as

$$
\beta_{m, i}=\frac{1+K_{n, i}}{1+0.377 K_{n, i}+\frac{4}{3} \alpha^{-1} K_{n, i}+\frac{4}{3} \alpha^{-1} K_{n, i}^{2}},
$$

where $K_{n, i}$ is the Knudsen number for the size class $i$ and the mass accommodation coefficient $\left(\alpha^{-1}\right)$ is assumed as unity.

\section{RESULTS AND DISCUSSION}

\section{Aerosol Particle Concentrations in Different Size Regimes}

Figure 1 shows the box and whiskers plot of monthly averaged aerosol particle number concentration for different modes. The maximum aerosol number concentration for an individual day is recorded in December with a value of $16.67 \times 10^{3} \mathrm{~cm}^{-3}$. The mode wise analysis of number concentration shows that Aitken mode $(30-100 \mathrm{~nm})$ dominates in the study region throughout the year with a maximum mean concentration during the post monsoon season $\left(9.6 \times 10^{3} \mathrm{~cm}^{-3}\right)$. Accumulation and nucleation mode particles are minimal compared to the Aitken mode particles during the entire study period at the sampling site. However, seasonal patterns showed variations in both the modes. Nucleation mode particles are high in number than accumulation mode particles during summer and monsoon seasons, whereas accumulation mode particles dominate during the other two seasons in comparison with nucleation mode. High mean concentration of nucleation mode particles $\left(4.67 \times 10^{3} \mathrm{~cm}^{-3}\right)$ 


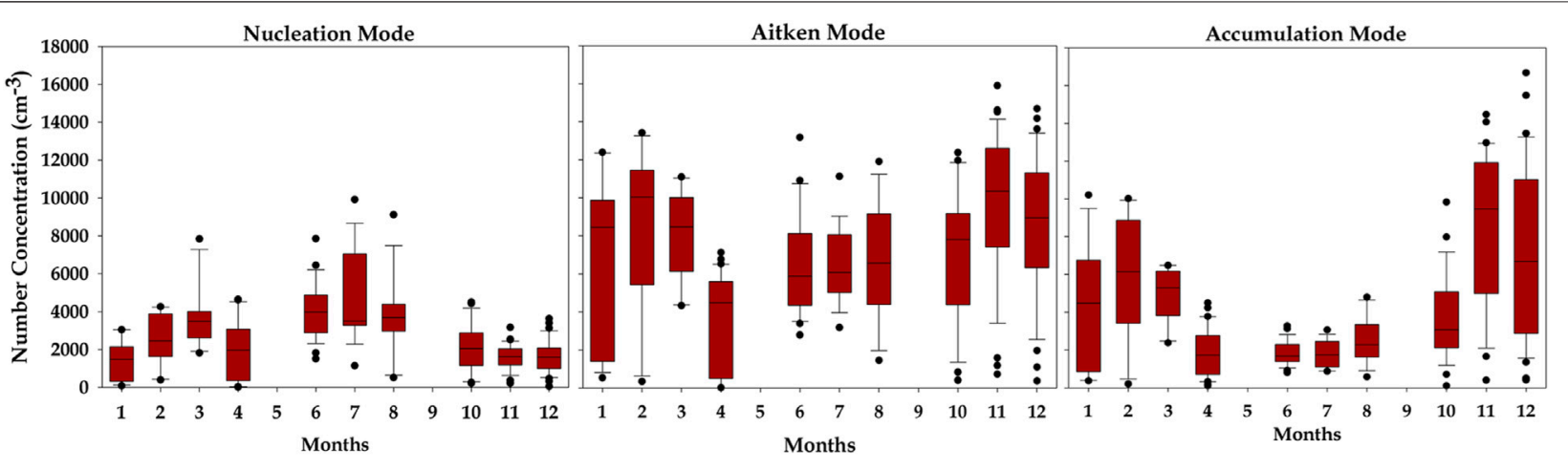

FIGURE 1 | Box and whiskers plot of monthly averaged number concentration for each mode. Horizontal line on the box shows the median of the data. Lower and upper end shows the 25th and 75th percentile of the data.

TABLE 1 | Seasonal mean number concentration for different particle modes at Delhi.

\begin{tabular}{|c|c|c|c|c|}
\hline Seasons & $N_{5-30}\left(10^{3} \mathrm{~cm}^{-3}\right)$ & $\mathrm{N}_{30-100}\left(10^{3} \mathrm{~cm}^{-3}\right)$ & $N_{100-1000}\left(10^{3} \mathrm{~cm}^{-3}\right)$ & $N_{5-1000}\left(10^{3} \mathrm{~cm}^{-3}\right)$ \\
\hline Winter & $1.85 \pm 0.65$ & $7.76 \pm 1.51$ & $5.35 \pm 1.58$ & $15.0 \pm 3.53$ \\
\hline Pre Monsoon & $2.73 \pm 1.54$ & $5.17 \pm 2.76$ & $2.59 \pm 1.57$ & $10.5 \pm 5.50$ \\
\hline Monsoon & $4.06 \pm 0.53$ & $6.73 \pm 0.26$ & $2.26 \pm 0.41$ & $13.0 \pm 0.16$ \\
\hline Post Monsoon & $1.83 \pm 0.38$ & $8.09 \pm 1.48$ & $5.90 \pm 3.17$ & $15.8 \pm 4.26$ \\
\hline
\end{tabular}

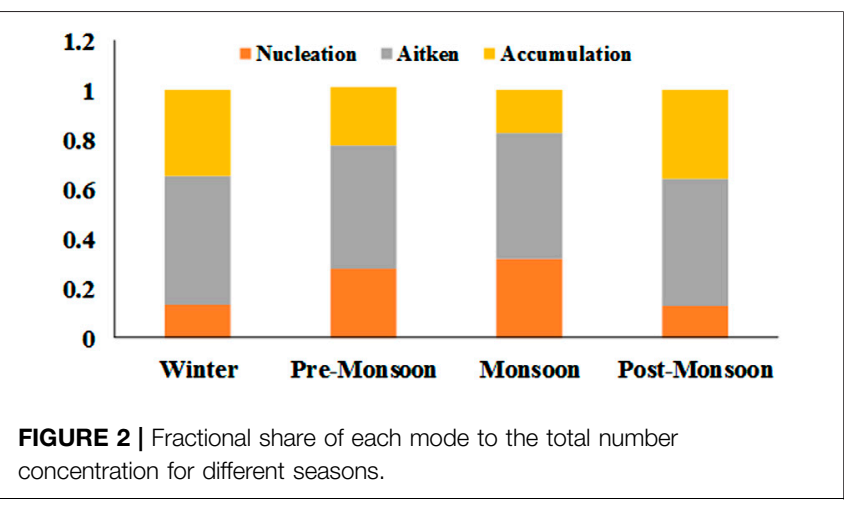

are noticed during July, when the minimum mean concentration of accumulation mode particles $\left(1.79 \times 10^{3} \mathrm{~cm}^{-3}\right)$ are registered. Wet deposition of accumulation mode particles could be a plausible reason for the decreased concentration of accumulation mode particles and increased concentration of nucleation mode particles in the monsoon season. Heat map analysis of aerosol particle size distribution revealed a considerable shift in the size of particle as it moves from winter to pre monsoon.

The seasonal mean number concentrations of aerosol particles in different modes are tabulated in Table 1. Here, $\mathrm{N}_{5-30}$ indicates number concentration in nucleation mode, $\mathrm{N}_{30-100}$ in Aitken mode and $\mathrm{N}_{100-1000}$ in accumulation mode. Highest average total number concentration of $15.80 \pm 4.26 \times 10^{3} \mathrm{~cm}^{-3}$ is noted during the post monsoon season, this can be attributed to the biomass burning events during the post monsoon seasons from nearby agrarian states like Punjab and Haryana. Mean total number concentration for the entire experimental period is found to be $14.08 \pm 7.60 \times 10^{3} \mathrm{~cm}^{-3}$. Fractional share of each mode to the total number concentration is shown in Figure 2. The highest concentration of nucleation mode particles were observed during monsoon season with the mean number concentration reaching up to $4.06 \pm 0.53 \times 10^{3} \mathrm{~cm}^{-3}$ with a fractional share of 0.315 . The maximum number concentration of accumulation mode particle was found to be $5.90 \pm 3.17 \times 10^{3} \mathrm{~cm}^{-3}$ in post monsoon season with a fractional share of 0.36 . A considerable increase in the accumulation mode particles is seen during post monsoon and winter season as the major contributor for accumulation mode particles come from biomass burning activity (Chen et al., 2017; Ghosh et al., 2019).

Figure 3 depicts the diurnal variation in mean number concentration for different seasons. Aitken mode is the primary peak and follows a bimodal pattern for all the seasons. Starting from a gradual increase from early morning Aitken mode reaches a peak value at about 09:00-10:00 AM and then decreases. Aitken mode again shows an increase in concentration during the evening hours which later dies out at late night. This high particle concentration during the morning and evening hours is associated with the high rush of traffic during these hours. Among the two Aitken mode peaks observed, evening peak is seen to be prominent with higher concentration of Aitken mode particles, which may be due to the boundary layer dynamics associated with the diurnal meteorology. The decrease in the concentration of Aitken mode particle after the morning peak hours can be attributed to the mixing of air due to increased convection as the temperature increases and the increased concentration at the evening hours may be attributed to the stable layer formation during the evening, trapping the pollutants 

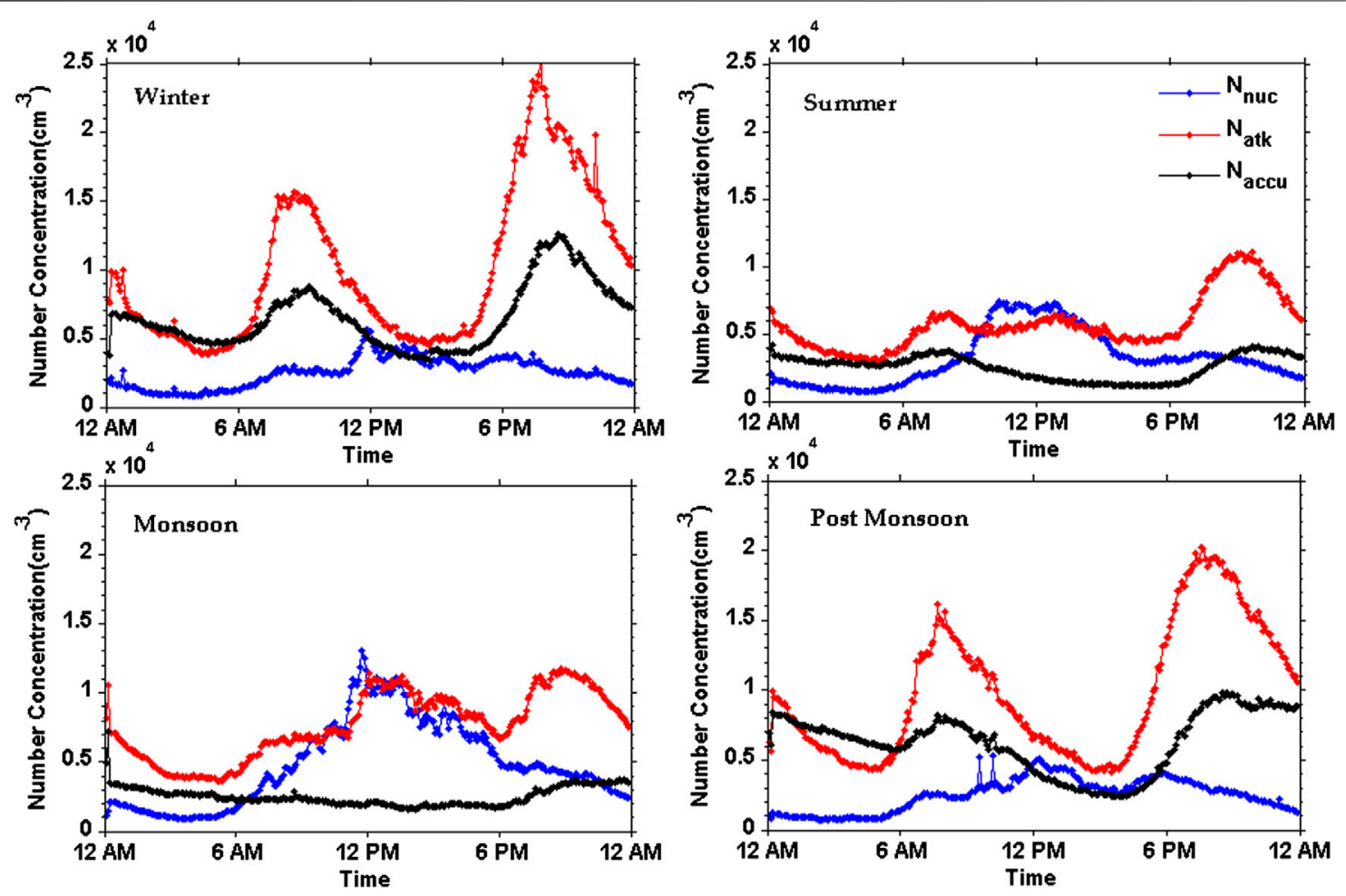

FIGURE 3 | Mean diurnal variation of number concentration in different particle modes at Delhi for the year 2012 for Winter (25 days), Summer (68 days), Monsoon (35 days) and Post Monsoon (41 days). Sample size for each season is mentioned in the bracket.

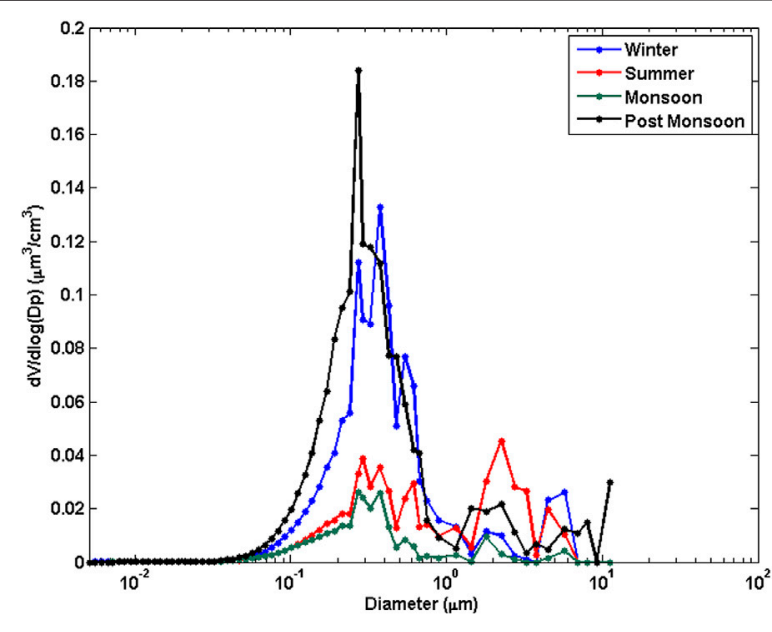

FIGURE 4 | Seasonal aerosol volume size-distribution at Delhi.

inside the boundary layer (Mönkkönen et al., 2005). The pattern shows a similar trend in all seasons except for monsoon season, where the peak concentration is observed in the midday. The morning peak Aitken mode is succeeded by a small increase in nucleation mode particles during midday on few days and some of it later grows to nucleation events which are discussed in the following session.
Figure 4 shows the aerosol volume size distribution for different seasons. Bimodal pattern is observed for volume size distribution, characterizing fine $(<1 \mu \mathrm{m})$ and coarse mode $(>1 \mu \mathrm{m})$. For volume size distribution fine mode dominates and peaks at 0.38 and $0.27 \mu \mathrm{m}$ for winter and post monsoon respectively. Coarse mode dominates during summer season and peaks at $2.25 \mu \mathrm{m}$. Increase in coarse mode particles during summer could be due to the high dust episodes (Mishra and Shibata, 2012) in the study location. Fine mode dominates for monsoon with a tiny peak at $0.38 \mu \mathrm{m}$. High volume concentration is noticed during the winter and post monsoon seasons with maximum volume concentration during November. Increased concentration of accumulation mode particles due to the surge in biomass burning activities could be the possible reason for the high volume concentration during post-monsoon season. It has also been noted that coarse mode particles are less predominant in these seasons and constitute a very feeble peak in the size distribution.

There haven't been many studies on long term measurements of aerosol number size distribution over Delhi. Hyvärinen et al. (2010) studied Gual Pahari, a semi urban area near Delhi and reported increase in nucleation and Aitken mode particles in summer and monsoon seasons, whereas accumulation mode was seen dominant during winter season. They also reported high particle concentration during the winter season. A study by Kumar et al., 2018 looked at the seasonal variation of size distribution in size segregated aerosols and found $\mathrm{PM}_{0.95}$ as 

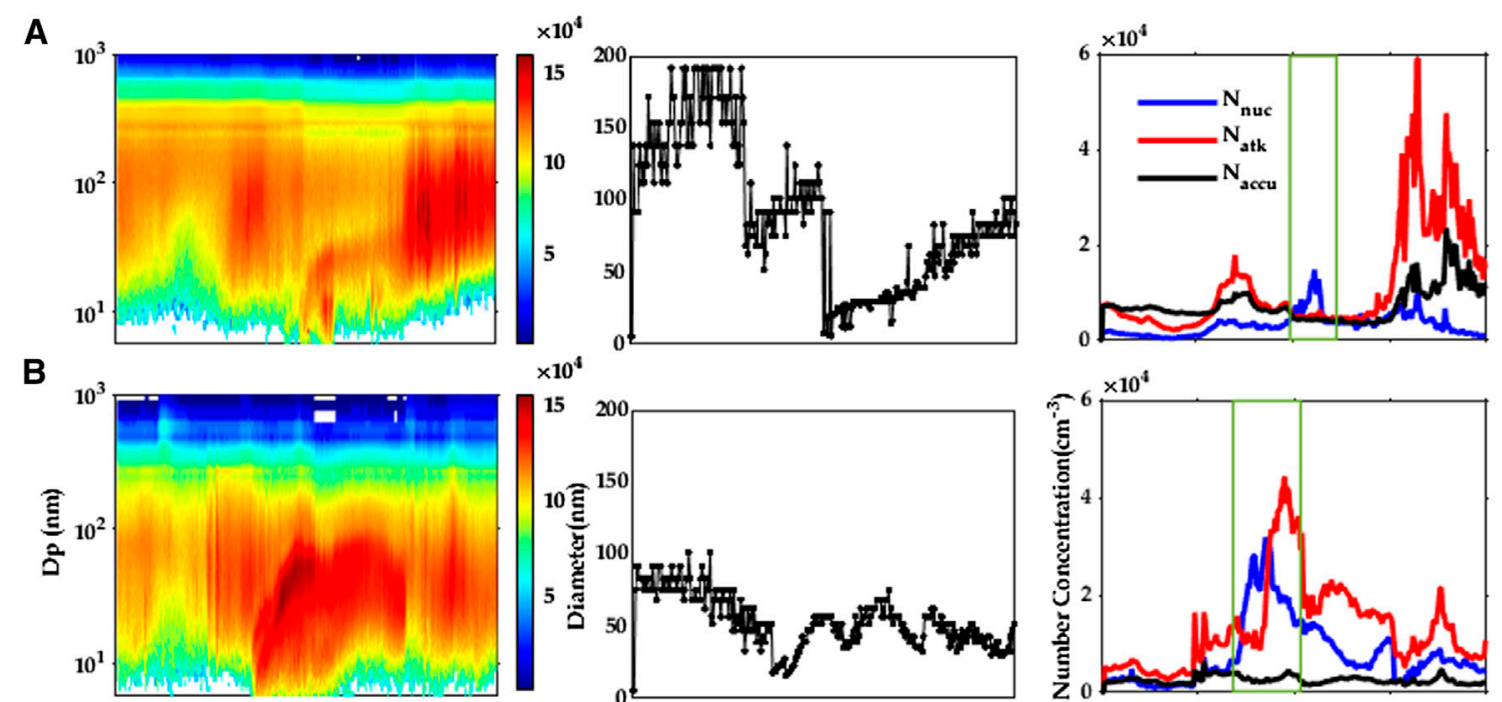

$\times 10^{4}$

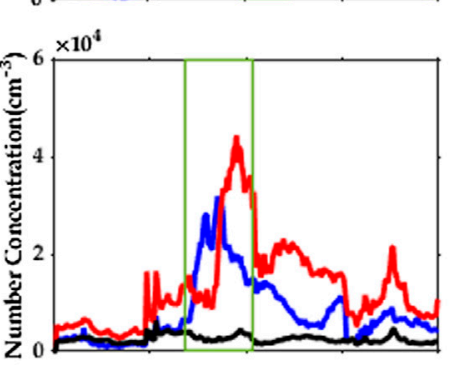

C
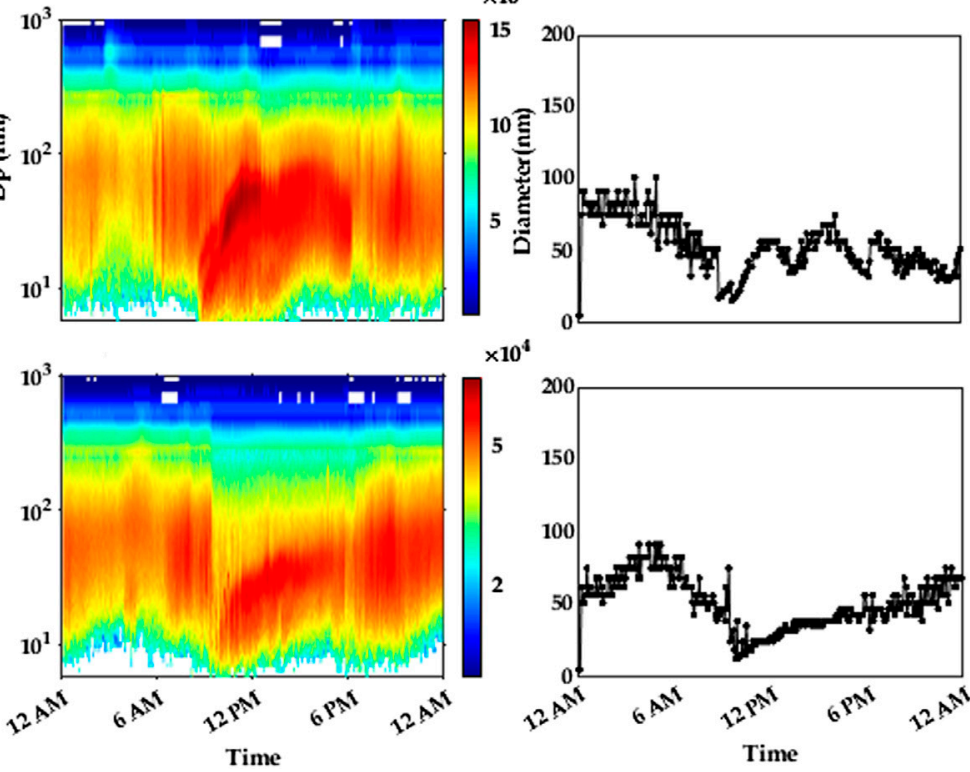

$\times 10^{4}$
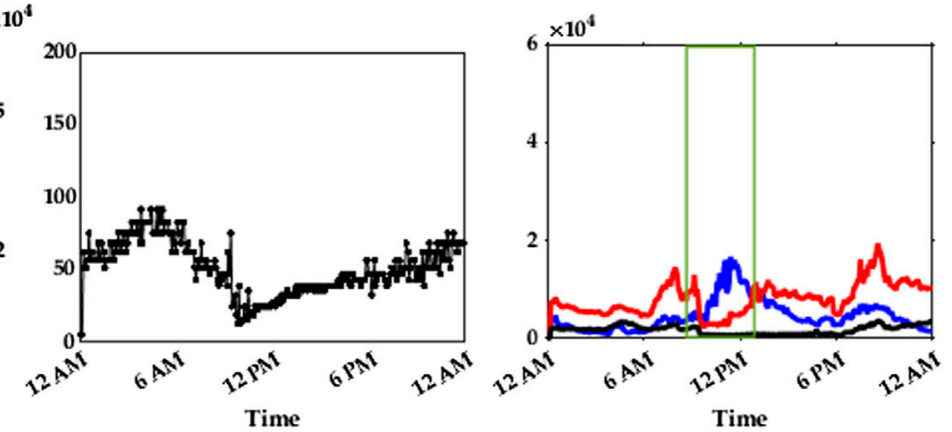

FIGURE 5 | Contour plots of typical NPF events at different seasons, its diurnal variation in mode diameters and mode wise number concentration for winter (February 13, 2012), (Panel A); summer (June 06, 2012), (Panel B); and monsoon (July 16, 2012), (Panel C). The rectangular box shows the time period of NPF event and the colour scale of contour plot denotes dN/dlog Dp (particles/cm³).

the dominant fraction in $\mathrm{PM}_{10}$ concentration. Another recent study by Gani et al. (2020) has reported the long term measurements of aerosol size distribution over the megacity Delhi. They suggest that accumulation mode particle contributes the most to the $\mathrm{PM}_{2.5}$ mass concentration over Delhi. Our result is in consistent with the above studies with high concentration of Aitken mode particle during all the four seasons of the Delhi with increase in accumulation mode particles during winter season.

\section{NPF Events: Observations and Characteristics}

As discussed in the previous section, diurnal variation of aerosol particles showed an increase in nucleation mode particles during midday and warranted for further investigation. Hence, contour plots of aerosol size distribution have been done. Sudden burst of nucleation mode particles, revealing a banana type of growth were noticed from the contour plots. Further analyzing the mode diameter during the event shows a sudden dip towards the nucleation mode confirming the initiation of New Particle Formation (NPF). Contour plots of selected NPF event days of different seasons are shown in Figure 5 along with their diurnal variations in the mode diameter and mode wise number concentration. It shows that NPF events are generally observed at midday during the winter, summer and monsoon periods. A clear sudden burst of nucleation mode particles for a period of few hours is visible at all these days pointing to the NPF events (Dal Maso et al., 2005). The NPF starts at around 10:00 LT in the morning and continue to grow till 14:00 LT. Associated increase in number concentration on nucleation mode can also be seen in Figure 5. Aitken and nucleation mode are the dominant modes over the sampling site during the event days except for winter. The NPF event is preceded by an elevated Aitken mode particle concentration which drops as the NPF commences. During the NPF event time, $\mathrm{N}_{5-30}$ shows a peak growth. In the representative figures for NPF events highest increase in nucleation mode number concentration events are seen during summer, which reaches $\sim 3.1 \times 10^{4} \mathrm{~cm}^{-3}$, following which the particle concentration decreases and continues to grow in Aitken mode which reaches a maximum concentration of $\sim 4.5 \times$ $10^{4} \mathrm{~cm}^{-3}$.

From a total of 222 days of data, 17 (8.4\%) NPF event days have been identified along with $28(\sim 12.4 \%)$ no NPF events days. 
TABLE 2 | Summary of the NPF events for different seasons at Delhi.

\begin{tabular}{|c|c|c|c|}
\hline \multirow[t]{2}{*}{ Date } & \multirow[t]{2}{*}{ Time period } & \multirow{2}{*}{$\begin{array}{c}\mathrm{GR}_{\text {nuc }} \\
\text { (nm/h) }\end{array}$} & \multirow{2}{*}{$\frac{\mathrm{CS}_{\mathrm{avg}}}{\left(10^{-3} \mathrm{~s}^{-1}\right)}$} \\
\hline & & & \\
\hline \multicolumn{4}{|l|}{ Summer } \\
\hline 31-03-2012 & $9: 00-17: 00$ & 1.8 & $6.59 \pm 2.68$ \\
\hline 03-04-2012 & 10:45-18:00 & 4.7 & $6.38 \pm 3.83$ \\
\hline 20-04-2012 & 10:30-13:30 & 6.8 & $5.73 \pm 7.93$ \\
\hline 21-04-2012 & $8: 00-12: 15$ & 3.7 & $3.31 \pm 1.53$ \\
\hline 24-04-2012 & $9: 30-14: 00$ & 18.46 & $4.23 \pm 3.25$ \\
\hline 27-04-2012 & 11:00-16:30 & 13.6 & $2.25 \pm 1.11$ \\
\hline 06-06-2012 & $9: 40-12: 30$ & 21.66 & $36.09 \pm 20.39$ \\
\hline 11-06-2012 & $9: 35-12: 45$ & 5.4 & $4.03 \pm 6.74$ \\
\hline 13-06-2012 & 8:30-11:30 & 10.2 & $11.12 \pm 4.14$ \\
\hline 18-06-2012 & 10:20-12:30 & 12.9 & $6.13 \pm 4.27$ \\
\hline 19-06-2012 & $9: 15-15: 00$ & 7.8 & $15.23 \pm 6.25$ \\
\hline 28-06-2012 & $9: 30-14: 30$ & 2.3 & $2.03 \pm 1.04$ \\
\hline \multirow[t]{2}{*}{ 30-06-2012 } & $9: 05-10: 50$ & 12.06 & $15.5 \pm 33.3$ \\
\hline & & $8.77 \pm 6.25$ & $9.31 \pm 8.82$ \\
\hline \multicolumn{4}{|l|}{ Monsoon } \\
\hline 04-07-2012 & $7: 40-14: 35$ & 4.8 & $4.93 \pm 2.60$ \\
\hline \multirow[t]{2}{*}{$16-07-2012$} & 10:00-18:00 & 5.7 & $6.07 \pm 2.29$ \\
\hline & & $5.25 \pm 0.64$ & $5.5 \pm 0.81$ \\
\hline \multicolumn{4}{|l|}{ Winter } \\
\hline 13-02-2012 & 12:35-16:00 & 4.39 & $3.49 \pm 1.13$ \\
\hline \multirow[t]{2}{*}{ 16-02-2012 } & $11: 15-13: 45$ & 3.91 & $1.91 \pm 0.73$ \\
\hline & & $4.15 \pm 0.34$ & $2.65 \pm 1.04$ \\
\hline
\end{tabular}

177 unidentified events have also been noted which corresponds to $78.2 \%$ of the total data. Unidentified events are those days in which high level of background noise are present making it difficult to comprehend the features of number-size distribution in the data. This background noise could be due to the pollution or haze condition in the atmosphere. Also, the days on which if there were any doubts regarding the identification of clear NPF events then such days have been classified as unidentified days. An important point to be noted here is that there might be hidden NPF events in this unidentified event days however, the background noise hinders it from quantifying the particle growth. Among the 17 NPF events, 13 occurred in summer season, 2 in winter season and 2 during monsoon season. No events were observed in the post monsoon season. All the NPF event days showed a banana type of growth that continued for several hours and matched the previously reported NPF events in literature (Junninen et al., 2008; Lee et al., 2008). To understand the characteristics of new particle formation during all the seasons, the growth rate and condensation sink parameters have been studied.

Table 2 summarizes the time period of the nucleation event, growth rate and condensation sink of the particle for different seasons. Almost all events start at much lower range in nucleation mode $(<20 \mathrm{~nm})$. Growth Rate for nucleation mode $\left(\mathrm{GR}_{\text {nuc }}\right)$ particle is determined for the event days. In summer it ranges from $1.8 \mathrm{~nm} / \mathrm{h}$ to $21.66 \mathrm{~nm} / \mathrm{h}$ with a mean of $8.77 \pm 6.25 \mathrm{~nm} / \mathrm{h}$. On a few occasions, a comparatively high $\mathrm{GR}_{\text {nuc }}$ values were observed during the summer. Such high values of GR indicate the lesser time for the growth of nucleation mode particles. In monsoon $\mathrm{GR}_{\text {nuc }}$ is noted to be about $4.8 \mathrm{~nm} / \mathrm{h}$ and $5.7 \mathrm{~nm} / \mathrm{h}$ with a mean of $5.25 \pm 0.64 \mathrm{~nm} / \mathrm{h}$ for the two events. Two daytime
NPF events were observed during winter period whose $\mathrm{GR}_{\text {nuc }}$ were $4.4 \mathrm{~nm} / \mathrm{h}$ and $3.91 \mathrm{~nm} / \mathrm{h}$ respectively. The mean $\mathrm{GR}_{\text {nuc }}$ for summer and monsoon are comparatively higher than winter nucleation rates. Further, the $\mathrm{GR}_{\text {nuc }}$ values of the present study at Delhi are slightly higher when compared with the regions such as Idaho hill (Weber et al., 1997); Ontario (Verheggen and Mozurkewich, 2002); Germany (Birmili et al., 2003) and Hyytiala, Finland (Dal Maso et al., 2007) but it is quite comparable with the GR values at most of the Indian locations reported, like Pune (Kamra et al., 2015); Kanpur (Kanawade et al., 2014) and Hanle, (Kompalli et al., 2014). At the coastal location of Trivandrum, however, the GR values are reported to be high (Kompalli et al., 2014) than that at Delhi.

\section{Discussion}

Being a very polluted environment, the frequency of NPF events is notably less in Delhi. Out of 222 days, only 17 NPF events have been observed with maximum events $(73.6 \%)$ occurring during the summer months and no NPF events reported during the post monsoon season. A number of factors influence the occurrence of NPF events at regional level including the abundance of precursor gases, pre-existing particle, solar radiation and the local meteorological conditions (Kerminen et al., 2018).

One of the influential factors for local NPF event is the amount of ambient gaseous $\mathrm{H}_{2} \mathrm{SO}_{4}$ concentration, owing to its inherent connection to the gas phase chemistry associated with aerosol nucleation and subsequent growth (Lee et al., 2019). The solar radiation also acts as a driver for the new particle formation as it controls the formation of $\mathrm{OH}$ radicals and the concentration of $\mathrm{H}_{2} \mathrm{SO}_{4}$ in the air (Pirjola et al., 1998; Dada et al., 2017). A decrease in the intensity of UV radiation tends to decrease the nucleation and the NPF events (Hamed et al., 2011; Baranizadeh et al., 2014). Stanier et al. (2004) used data of $\mathrm{UVxSO}_{2}$ as a proxy to $\mathrm{H}_{2} \mathrm{SO}_{4}$ and correlated it with the condensation sink (CS) data to see the conditions that favor nucleation. He found that for the same value of $\mathrm{UVxSO}_{2}$, nucleation took place at higher $\mathrm{CS}$ value during summer.

To analyse the possible mechanism for NPF events over the study region, we have studied different governing factors conducive for NPF events at selected dates from June 12, 2012 to June 18, 2012 for summer and February 13, 2012 to February 17,2012 for winter. The time period is chosen in such a way that at least two NPF events are present for both the seasons and in accordance with the availability of $\mathrm{SO}_{2}$ data. Monsoon events are not studied here, due to the unavailability of $\mathrm{SO}_{2}$ data. As $\mathrm{H}_{2} \mathrm{SO}_{4}$ data is unavailable for the study site, product of $\mathrm{SO}_{2}$ and $\mathrm{UV}$ is used as a proxy to understand the chemistry on event and nonevent days. In the present study hourly data of $\mathrm{UVxSO}_{2}$ and condensation sink (CS) is correlated for event and nearby nonevent days and plotted for the time window of 8:00 LT to 16:00 LT, keeping in view the occurrence of NPF events (Figure 6). It may be noticed that high CS and high $\mathrm{UVxSO}_{2}$ is observed for $\mathrm{NPF}$ event day in summer and low CS and high $\mathrm{UVxSO}_{2}$ was favorable for the NPF events in winter. We have also found that for the similar $\mathrm{UVxSO}_{2}$ value nucleation takes place at higher CS values during summer as compared to winter. Unlike Stanier et al. (2004), where nucleation is usually more prominent on the right 

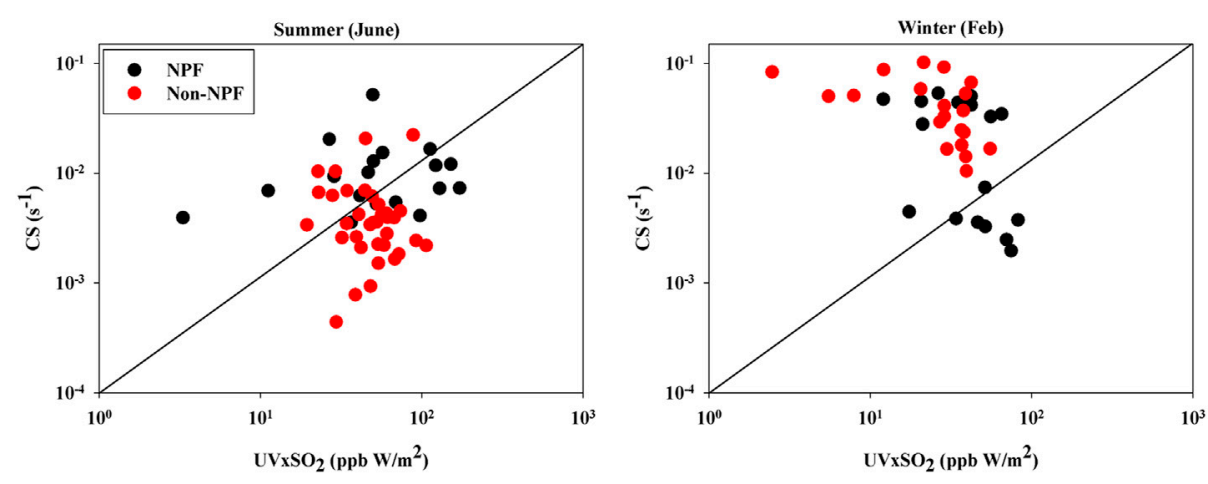

FIGURE 6 | Scatter plot showing the distribution of NPF and non NPF event in accordance to Stanier et al. (2004) method. Hourly averaged data point is shown in the figure.
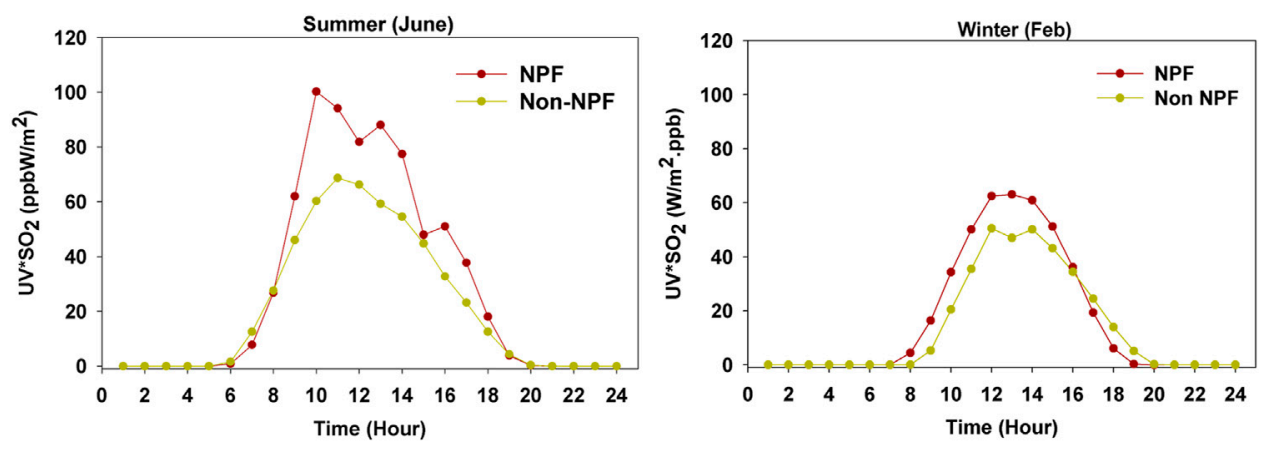

FIGURE 7 | Diurnal variation of $\mathrm{UV}^{*} \mathrm{SO}_{2}$ (proxy for $\mathrm{H}_{2} \mathrm{SO}_{4}$ ) for NPF and non NPF days over the study site.

side of the diagonal, our study do not show such clear preferences, possibly due to the presences of other predictive variables such as relative humidity, concentration of pre-existing particles and prevailing meteorological conditions.

Over our study site, the amount of incoming solar radiation (both in shortwave and UV range) varies significantly during the summer and winter seasons. In summers, the day-time (7 AM-5 PM) shortwave and UV flux increase by 52 and $61 \%$ respectively, from the corresponding winter values. Thus, the abundant solar insolation during summer season (high UV) makes summer months more conducive for new particle formation, and this could be one of the plausible reasons for the increased NPF events during summer season. We have also looked at the diurnal variation of $\mathrm{UVxSO}_{2}$ for event days and non-event days as plotted in Figure 7. It shows the diurnal variation in $\mathrm{UVxSO}_{2}$ for June (summer) and February (winter). Considerable increase in $\mathrm{UVxSO}_{2}$ is noticed during summer NPF days compared to the non-event days in summer. A similar result is seen for winter NPF event days also. However, the difference between NPF event and non-event days is much less during winter month. This also suggests that the abundant UV radiation along with high concentration of $\mathrm{SO}_{2}$ (Figure 8) during the summer months could be the reason for the increased NPF event over the study region. A recent study by Jokinen et al. (2017) revealed the significance of photochemistry in NPF by studying the NPF event during a partial solar eclipse day. He demonstrated the decrease in $\mathrm{H}_{2} \mathrm{SO}_{4}$ due to decrease in UV during the eclipse time resulting in decreased nucleation events. Thus, the strong gas phase chemistry owing to the high UV radiation coupled with abundant precursor gas concentration $\left(\mathrm{SO}_{2}\right)$ could be the reason for the high NPF events reported during the summer period over the study site.

Some of the previous studies have also shown that RH is negatively correlated with continental NPF events (Hamed et al., 2011; Dada et al., 2017). Increase in condensation and coagulation sink have been observed generally during high $\mathrm{RH}$ days, owing to the hygroscopic growth by pre-existing aerosol particles due to high intake of water vapor, leading to larger loss of condensable vapor such as $\mathrm{H}_{2} \mathrm{SO}_{4}$ (Hamed et al., 2011). This may lead to much smaller nucleation rates or nucleation events. In our study, however, we have found that most of the NPF event occurred at $\mathrm{RH}$ less than $40 \%$. As the number of NPF events are also less in the present case and mostly observed below $40 \%$ $\mathrm{RH}$, a correlation between NPF event and the RH could not be established here.

In order to see the distribution of preexisting particles over the study area we have looked at the $\mathrm{PM}_{10}, \mathrm{PM}_{2.5}$ and $\mathrm{SO}_{2}$ concentration over the study region. Figure 8 shows the distribution of $\mathrm{PM}_{10}, \mathrm{PM}_{2.5}$ and $\mathrm{SO}_{2}$ over the selected time window for the NPF and non-NPF days. Comparatively less 

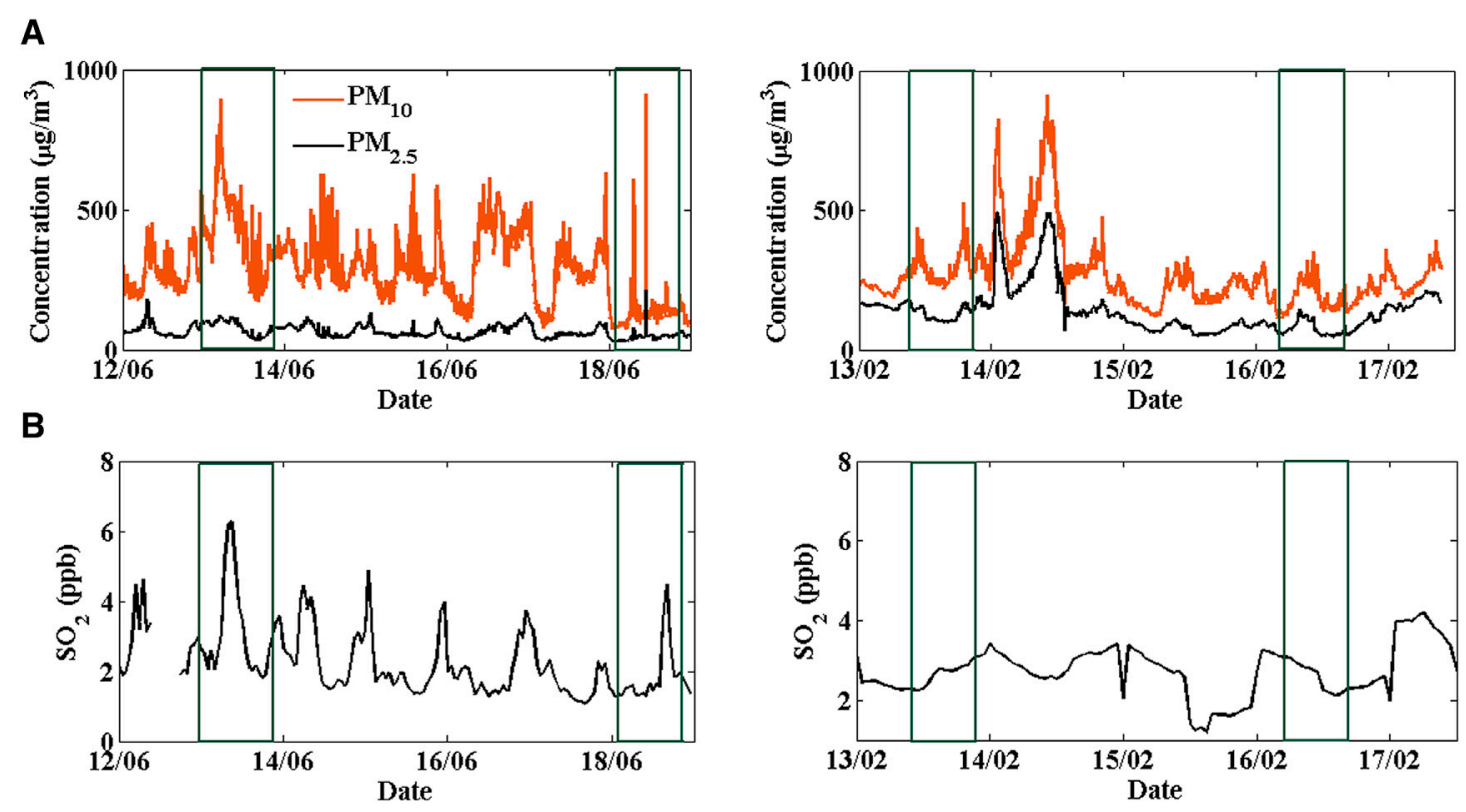

FIGURE 8 | (A) $\mathrm{PM}_{10}$ and $\mathrm{PM}_{2.5}$ concentration for NPF and non NPF events for summer (left) and winter (right) season. The rectangular box represents the NPF day data points. (B) Temporal variation of $\mathrm{SO}_{2}$ for NPF and non NPF event days for summer (left) and winter (right).

$\mathrm{PM}_{10}$ concentration is observed for NPF days than the non NPF event days for both seasons which is in accordance with previous literatures. However, high $\mathrm{PM}_{10}$ concentration is noticed for the summer NPF event on June 13, 2012 reaching up to $900 \mu \mathrm{g} / \mathrm{m}^{3}$. $\mathrm{SO}_{2}$ concentration is also seen high on this day reaching to a concentration of $6 \mathrm{ppb}$. Delhi experiences high dust activity during summer months, could be a possible reason for the high $\mathrm{PM}_{10}$ on the particular day. Compared to non-event days in summer, high $\mathrm{CS}$ and high $\mathrm{PM}_{10}$ concentration have been noticed for NPF event days. This is a deviation from the usual NPF mechanism. However high CS along with high preexisting particle has also been noticed during NPF events in other regions as well (Yue et al., 2009; Nie et al., 2014). Study by Nie et al. (2014) suggest a possible mechanism for the dust induced NPF event, through dust induced heterogeneous photo catalytic reactions producing $\mathrm{OH}$ radicals enhancing the $\mathrm{SO}_{2}$ production. Our study using proxy data for $\mathrm{H}_{2} \mathrm{SO}_{4}$ suggests the strong gas phase chemistry owing to the high UV radiation coupled with abundant precursor gas concentration $\left(\mathrm{SO}_{2}\right)$ could be the reason for the high NPF events reported during the summer period over the study site.

\section{CONCLUSION}

Monthly and seasonal characteristics of the size distribution and number concentration of aerosol particles in the size range of $5 \mathrm{~nm}-32 \mu \mathrm{m}$ have been studied at Delhi using GRIMM-WRAS during December 2011 to January 2013 along with the simultaneous measurements of $\mathrm{SO}_{2}, \mathrm{RH}$ and solar radiation flux in the UVrange. The findings of the study may be summarized as below:
The mean number concentration at Delhi during the entire experimental period is $14.08 \pm 7.60 \times 10^{3} \mathrm{~cm}^{-3}$ with highest concentration during post-monsoon $\left(15.8 \pm 4.26 \times 10^{3} \mathrm{~cm}^{-3}\right)$ followed by winter $\left(15.0 \pm 3.5 \times 10^{3} \mathrm{~cm}^{-3}\right)$, monsoon $(13.0 \pm 0.2 \times$ $\left.10^{3} \mathrm{~cm}^{-3}\right)$ and summer $\left(10.5 \pm 5.5 \times 10^{3} \mathrm{~cm}^{-3}\right)$. Study site is dominated by Aitken mode particle which follows a bimodal pattern in diurnal variation having peaks during morning and evening traffic hours. Accumulation mode particles are scarce over the study location except during the winter and postmonsoon days, when it shows a bimodal secondary peak along with the primary Aitken mode particle. The volume size distribution is also characterized by two modes, fine and coarse. Fine mode dominates during all the seasons except summer, when coarse mode dominates.

From 222 days of WRAS data, a total of 17 NPF events (13 in summer, 2 in winter and 2 during monsoon) have been observed. No NPF events were observed during post-monsoon season. During NPF events the Aitken and nucleation mode particles contribute more to the number concentration. The nucleation growth rate during summer and monsoon are more or less comparable and vary in the range of a few $\mathrm{nm} / \mathrm{h}$ to $\sim 20 \mathrm{~nm} / \mathrm{h}$, whereas, during winters it is much smaller in the range.

Our study on selected time period of NPF events show that high UV, low water vapor and low CS are favorable conditions for NPF events in winter. However, for summer high CS values are observed for NPF days, an aberration from previous studies, with increased $\mathrm{PM}_{10}$ and $\mathrm{SO}_{2}$ concentration in the background. This could be due to a possible NPF pathway through dust induced photo catalytic production of $\mathrm{SO}_{2}$. Proxy study using $\mathrm{UVxSO} 2$ points to the strong influence of gas phase chemistry during summer months and hence the high frequency of NPF events. Myriads of factors contribute to NPF event. A detailed study of 
precursor gases and VOCs are also required to reach conclusion on different mechanisms for NPF events on both seasons at the study site.

\section{DATA AVAILABILITY STATEMENT}

The raw data supporting the conclusion of this article will be made available by the authors, without undue reservation.

\section{AUTHOR CONTRIBUTIONS}

SJ: Execution, software and Programming, graphs and manuscript preparation. AM: Conceptualization, editing. NL:

\section{REFERENCES}

Andreae, M. O., Rosenfeld, D., Artaxo, P., Costa, A. A., Frank, G. P., Longo, K. M., et al. (2004). Smoking Rain Clouds over the Amazon. Science 303, 1337-1342. doi:10.1126/science.1092779

Bano, T., Singh, S., Gupta, N. C., and John, T. (2013). Solar Global Ultraviolet and Broadband Global Radiant Fluxes and Their Relationships with Aerosol Optical Depth at New Delhi. Int. J. Climatol. 33, 1551-1562. doi:10.1002/joc.3534

Baranizadeh, E., Arola, A., Hamed, A., Nieminen, T., Mikkonen, S., Virtanen, A., et al. (2014). The Effect of Cloudiness on New-Particle Formation: Investigation of Radiation Levels. Bor. Environ. Res. 19, 343-354.

Bäumer, D., Vogel, B., Versick, S., Rinke, R., Möhler, O., and Schnaiter, M. (2008). Relationship of Visibility, Aerosol Optical Thickness and Aerosol Size Distribution in an Ageing Air Mass over South-West Germany. Atmos. EnvironmentEnviron 42, 989-998. doi:10.1016/j.atmosenv.2007.10.017

Bergin, M. H., Greenwald, R., Xu, J., Berta, Y., and Chameides, W. L. (2001). Influence of Aerosol Dry Deposition on Photosynthetically Active Radiation Available to Plants: A Case Study in the Yangtze delta Region of China. Geophys. Res. Lett. 28, 3605-3608. doi:10.1029/2001gl013461

Bhandari, S., Gani, S., Patel, K., Wang, D. S., Soni, P., Arub, Z., et al. (2020). Sources and Atmospheric Dynamics of Organic Aerosol in New Delhi, India: Insights from Receptor Modeling. Atmos. Chem. Phys. 20, 735-752. doi:10.5194/acp-20735-2020

Birmili, W., Berresheim, H., Plass-Dülmer, C., Elste, T., Gilge, S., Wiedensohler, A., et al. (2003). The Hohenpeissenberg Aerosol Formation experiment (HAFEX): a Long-Term Study Including Size-Resolved Aerosol, H2SO4, OH, and Monoterpenes Measurements. Atmos. Chem. Phys. 3 (2), 361-376. doi:10.5194/acp-3-361-2003

Boucher, O., Randall, D., Artaxo, P., Bretherton, C., Feingold, G., Forster, P., et al. (2013). Clouds and Aerosols: The Physical Science Basis. Contribution of Working Group I to the Fifth Assessment Report of the Intergovernmental Panel on Climate Change. Cambridge: Cambridge University Press.

Chameides, W. L., Yu, H., Liu, S. C., Bergin, M., Zhou, X., Mearns, L., et al. (1999). Case Study of the Effects of Atmospheric Aerosols and Regional Haze on Agriculture: An Opportunity to Enhance Crop Yields in China through Emission Controls? Proc. Natl. Acad. Sci. 96, 13626-13633. doi:10.1073/ pnas.96.24.13626

Chen, J., Li, C., Ristovski, Z., Milic, A., Gu, Y., Islam, M. S., et al. (2017). A Review of Biomass Burning: Emissions and Impacts on Air Quality, Health and Climate in China. Sci. Total Environ. 579, 1000-1034. doi:10.1016/j.scitotenv.2016.11.025

Chowdhury, S., Dey, S., Tripathi, S. N., Beig, G., Mishra, A. K., and Sharma, S. (2017). "Traffic Intervention" Policy Fails to Mitigate Air Pollution in Megacity Delhi. Environ. Sci. Pol. 74, 8-13. doi:10.1016/j.envsci.2017.04.018

Dada, L., Paasonen, P., Nieminen, T., Buenrostro Mazon, S., Kontkanen, J., Peräkylä, O., et al. (2017). Long-term Analysis of clear-sky New Particle Formation Events and Nonevents in Hyytiälä. Atmos. Chem. Phys. 17 (10), 6227-6241. doi:10.5194/acp-17-6227-2017
Observation and Data. SSh: Observation and Data. SSi: Conceptualization, Supervision and editing.

\section{FUNDING}

A part of this work was sponsored by ISRO-GBP (Indian Space Research Organization-Geosphere Biosphere Program) under ARFI project (Grant No. 2792). One of the authors SJ would like to acknowledge the Department of Science and Technology (DST) for providing research grant under DST Inspire Fellowship scheme (DST/INSPIRE/2016/IF160279). One of the authors (AM) would also like to thank DST INSPIRE Faculty grant (DST/INSPIRE/04/2015/003253) and UPoE II (UGC) grant to provide necessary funds.

Dal Maso, M., Kulmala, M., Riipinen, I., Wagner, R., Hussein, T., Aalto, P. P., et al. (2005). Formation and Growth of Fresh Atmospheric Aerosols: Eight Years of Aerosol Size Distribution Data from SMEAR II. Hyytiala, Finland. Bor. Environ. Res. 10, 323.

Dusek, U., Frank, G. P., Hildebrandt, L., Curtius, J., Schneider, J., Walter, S., et al. (2006). Size Matters More Than Chemistry for Cloud-Nucleating Ability of Aerosol Particles. Science 312, 1375-1378. doi:10.1126/science.1125261

Fuchs, N. A., and Sutugin, A. G. (1971). "HIGH-DISPERSED AEROSOLS," in Topics in Current Aerosol Research International Reviews in Aerosol Physics and Chemistry Editor G. M. Hidy and J. R. Brock (Pergamon), 1. doi:10.1016/B9780-08-016674-2.50006-6

Gani, S., Bhandari, S., Patel, K., Seraj, S., Soni, P., Arub, Z., et al. (2020). Particle Number Concentrations and Size Distribution in a Polluted Megacity: the Delhi Aerosol Supersite Study. Atmos. Chem. Phys. 20, 8533-8549. doi:10.5194/acp20-8533-2020

Ghosh, A., Roy, A., Chatterjee, A., Das, S. K., Ghosh, S. K., and Raha, S. (2019). Impact of Biomass Burning Plumes on the Size-Segregated Aerosol Chemistry over an Urban Atmosphere at Indo-Gangetic Plain. Aerosol Air Qual. Res. 19, 163-180. doi:10.4209/aaqr.2017.12.0590

Gogoi, M. M., Babu, S. S., Arun, B. S., Moorthy, K. K., Ajay, A., Ajay, P., et al. (2021). Response of Ambient BC Concentration across the Indian Region to the Nation-wide Lockdown: Results from the ARFINET Measurements of. Curr. Sci. 120, 11. doi:10.18520/cs/v120/i2/341-351

Grimm, H., and Eatough, D. J. (2009). Aerosol Measurement: the Use of Optical Light Scattering for the Determination of Particulate Size Distribution, and Particulate Mass, Including the Semi-volatile Fraction. J. Air Waste Management Assoc. 59, 101-107. doi:10.3155/1047-3289.59.1.101

Hamed, A., Korhonen, H., Sihto, S. L., Joutsensaari, J., Järvinen, H., Petäjä, T., et al. (2011). The Role of Relative Humidity in continental New Particle Formation. J. Geophys. Res. Atmos. 116. doi:10.1029/2010jd014186

Hand, J. L., Kreidenweis, S. M., Eli Sherman, D., Collett, J. L., Hering, S. V., Day, D. E., et al. (2002). Aerosol Size Distributions and Visibility Estimates during the Big Bend Regional Aerosol and Visibility Observational (BRAVO) Study. Atmos. Environ. 36, 5043-5055. doi:10.1016/s1352-2310(02)00568-x

Harrison, R. M., and Yin, J. (2000). Particulate Matter in the Atmosphere: Which Particle Properties Are Important for its Effects on Health? Sci. Total Environ. 249, 85-101. doi:10.1016/s0048-9697(99)00513-6

Hyvärinen, A. P., Lihavainen, H., Komppula, M., Panwar, T. S., Sharma, V. P., Hooda, R. K., et al. (2010). Aerosol Measurements at the Gual Pahari EUCAARI Station: Preliminary Results from In-Situ Measurements. Atmos. Chem. Phys. 10, 7241-7252. doi:10.5194/acp-10-7241-2010

Jokinen, T., Kontkanen, J., Lehtipalo, K., Manninen, H. E., Aalto, J., Porcar-Castell, A., et al. (2017). Solar Eclipse Demonstrating the Importance of Photochemistry in New Particle Formation. Sci. Rep. 7, 45707. doi:10.1038/srep45707

Junninen, H., Hulkkonen, M., Riipinen, I., Nieminen, T., Hirsikko, A., Suni, T., et al. (2008). Observations on Nocturnal Growth of Atmospheric Clusters. Tellus B: Chem. Phys. Meteorology 60, 365-371. doi:10.1111/j.16000889.2008.00356.x 
Kamra, A. K., Siingh, D., Gautam, A. S., Kanawade, V. P., Tripathi, S. N., and Srivastava, A. K. (2015). Atmospheric Ions and New Particle Formation Events at a Tropical Location, Pune, India. Q.J.R. Meteorol. Soc. 141, 3140-3156. doi:10.1002/qj.2598

Kanawade, V. P., Tripathi, S. N., Siingh, D., Gautam, A. S., Srivastava, A. K., Kamra, A. K., et al. (2014). Observations of New Particle Formation at Two Distinct Indian Subcontinental Urban Locations. Atmos. Environ. 96, 370-379. doi:10.1016/j.atmosenv.2014.08.001

Kerminen, V.-M., Chen, X., Vakkari, V., Petäjä, T., Kulmala, M., and Bianchi, F. (2018). Atmospheric New Particle Formation and Growth: Review of Field Observations. Environ. Res. Lett. 13 (10), 103003. doi:10.1088/1748-9326/ aadf3c

Kompalli, S. K., Suresh Babu, S., Krishna Moorthy, K., Gogoi, M. M., Nair, V. S., and Chaubey, J. P. (2014). The Formation and Growth of Ultrafine Particles in Two Contrasting Environments: a Case Study. Ann. Geophys. 32, 817-830.

Kuang, C., McMurry, P. H., McCormick, A. V., and Eisele, F. L. (2008). Dependence of Nucleation Rates on Sulfuric Acid Vapor Concentration in Diverse Atmospheric Locations. J. Geophys. Res. 113, D10209. doi:10.1029/ 2007jd009253

Kuang, C., Riipinen, I., Sihto, S.-L., Kulmala, M., McCormick, A. V., and McMurry, P. H. (2010). An Improved Criterion for New Particle Formation in Diverse Atmospheric Environments. Atmos. Chem. Phys. 10, 8469-8480. doi:10.5194/ acp-10-8469-2010

Kulmala, M., Laakso, L., Lehtinen, K. E. J., Riipinen, I., Dal Maso, M., Anttila, T., et al. (2004). Initial Steps of Aerosol Growth. Atmos. Chem. Phys. 4, 2553-2560. doi:10.5194/acp-4-2553-2004

Kulmala, M., Maso, M. D., Mäkelä, J. M., Pirjola, L., Väkevä, M., Aalto, P., et al. (2001). On the Formation, Growth and Composition of Nucleation Mode Particles. Tellus B 53, 479-490. doi:10.1034/j.1600-0889.2001.530411.x

Kumar, P., Kumar, S., and Yadav, S. (2018). Seasonal Variations in Size Distribution, Water-Soluble Ions, and Carbon Content of Size-Segregated Aerosols over New Delhi. Environ. Sci. Pollut. Res. 25, 6061-6078. doi:10.1007/s11356-017-0954-6

Lee, S.-H., Young, L.-H., Benson, D. R., Suni, T., Kulmala, M., Junninen, H., et al. (2008). Observations of Nighttime New Particle Formation in the Troposphere. J. Geophys. Res. 113, D10210. doi:10.1029/2007jd009351

Lee, S. H., Gordon, H., Yu, H., Lehtipalo, K., Haley, R., Li, Y., et al. (2019). New Particle Formation in the Atmosphere: From Molecular Clusters to Global Climate. J. Geophys. Res. Atmos. 124 (13), 7098-7146. doi:10.1029/ 2018jd029356

Lighty, J. S., Veranth, J. M., and Sarofim, A. F. (2000). Combustion Aerosols: Factors Governing Their Size and Composition and Implications to Human Health. J. Air Waste Management Assoc. 50 (9), 1565-1618. doi:10.1080/ 10473289.2000.10464197

Liou, K. N. (1992). Radiation and Cloud Processes in the atmosphereTheory, Observation, and Modeling. United States: Oxford University Press.

Lodhi, N. K., Beegum, S. N., Singh, S., and Kumar, K. (2013). Aerosol Climatology at Delhi in the Western Indo-Gangetic Plain: Microphysics, Long-Term Trends, and Source Strengths. J. Geophys. Res. Atmos. 118, 1361-1375. doi:10.1002/jgrd.50165

Maso, M. D., Sogacheva, L., Aalto, P. P., Riipinen, I., Komppula, M., Tunved, P., et al. (2007). Aerosol Size Distribution Measurements at Four Nordic Field Stations: Identification, Analysis and Trajectory Analysis of New Particle Formation Bursts. Tellus B: Chem. Phys. Meteorology 59, 350-361. doi:10.1111/j.1600-0889.2007.00267.x

Metzger, A., Verheggen, B., Dommen, J., Duplissy, J., Prevot, A. S. H., Weingartner, E., et al. (2010). Evidence for the Role of Organics in Aerosol Particle Formation under Atmospheric Conditions. Proc. Natl. Acad. Sci. 107, 6646-6651. doi:10.1073/pnas.0911330107

Mishra, A. K., Klingmueller, K., Fredj, E., Lelieveld, J., Rudich, Y., and Koren, I. (2014). Radiative Signature of Absorbing Aerosol over the Eastern Mediterranean basin. Atmos. Chem. Phys. 14, 7213-7231. doi:10.5194/acp14-7213-2014

Mishra, A. K., and Shibata, T. (2012). Synergistic Analyses of Optical and Microphysical Properties of Agricultural Crop Residue Burning Aerosols over the Indo-Gangetic Basin (IGB). Atmos. Environ. 57, 205-218. doi:10.1016/j.atmosenv.2012.04.025
Mönkkönen, P., Koponen, I. K., Lehtinen, K. E. J., Hämeri, K., Uma, R., and Kulmala, M. (2005). Measurements in a Highly Polluted Asian Mega City: Observations of Aerosol Number Size Distribution, Modal Parameters and Nucleation Events. Atmos. Chem. Phys. 5, 57-66. doi:10.5194/acp-5-572005

Mukherjee, T., Asutosh, A., Pandey, S. K., Yang, L., Gogoi, P. P., Panwar, A., et al. (2018). Increasing Potential for Air Pollution over Megacity New Delhi: A Study Based on 2016 Diwali Episode. Aerosol Air Qual. Res. 18, 2510-2518. doi:10.4209/aaqr.2017.11.0440

Nie, W., Ding, A., Wang, T., Kerminen, V. M., George, C., Xue, L., et al. (2014). Polluted Dust Promotes New Particle Formation and Growth. Scientific Rep. 4, 6634. doi:10.1038/srep06634

Pant, P., Baker, S. J., Goel, R., Guttikunda, S., Goel, A., Shukla, A., et al. (2016). Analysis of Size-Segregated winter Season Aerosol Data from New Delhi, India. Atmos. Pollut. Res. 7 (1), 100-109.doi:10.1016/j.apr.2015.08.001

Pirjola, L., Laaksonen, A., Aalto, P., and Kulmala, M. (1998). Sulfate Aerosol Formation in the Arctic Boundary Layer. J. Geophys. Res. Atmos. 103 (D7), 8309-8321.

Ramanathan, V. C. P. J., Crutzen, P. J., Kiehl, J. T., and Rosenfeld, D. (2001). Aerosols, Climate, and the Hydrological Cycle. Science 294, 2119-2124. doi:10.1126/science.1064034

Ricklin, J. C., Hammel, S. M., Eaton, F. D., and Lachinova, S. L. (2006). Atmospheric Channel Effects on Free-Space Laser Communication. J. Opt. Fiber Commun. Res. 3, 111-158.doi:10.1007/978-0-387-28677-8_2

Rosenfeld, D., Lohmann, U., Raga, G. B., O’Dowd, C. D., Kulmala, M., Fuzzi, S., et al. (2008). Flood or Drought: How Do Aerosols Affect Precipitation? Science 321, 1309-1313.doi:10.1126/science.1160606

Salimi, F., Rahman, M., Clifford, S., Ristovski, Z., and Morawska, L. (2017). Nocturnal New Particle Formation Events in Urban Environments. Atmos. Chem. Phys. 17, 521-530. doi:10.5194/acp-17-521-2017

Sarangi, B., Aggarwal, S. G., and Gupta, P. K. (2015). A Simplified Approach to Calculate Particle Growth Rate Due to Self-Coagulation, Scavenging and Condensation Using SMPS Measurements during a Particle Growth Event in New Delhi. Aerosol Air Qual. Res. 15, 166-179. doi:10.4209/ aaqr.2013.12.0350

Seinfeld, J. H., and Pandis, S. N. (2016). Atmospheric Chemistry and Physics: From Air Pollution to Climate Change. John Wiley \& Sons.

Singh, A., and Dey, S. (2012). Influence of Aerosol Composition on Visibility in Megacity Delhi. Atmos. Environ. 62, 367-373. doi:10.1016/ j.atmosenv.2012.08.048

Singh, S., and Beegum, S. N. (2013). Direct Radiative Effects of an Unseasonal Dust Storm at a Western Indo Gangetic Plain Station Delhi in Ultraviolet, Short and Longwave Region. Geophys. Res. Lett. 40, 2444-2449. doi:10.1002/ grl.50496

Singh, S., Nath, S., kohli, R., and Singh, R. (2005). Aerosols over Delhi during Premonsoon Months: Characteristics and Effects on Surface Radiation Forcing. Geophys. Res. Lett. 32, L13808. doi:10.1029/2005GL023062

Singh, S., Soni, K., Bano, T., Tanwar, R. S., Nath, S., and Arya, B. C. (2010). ClearSky Direct Aerosol Radiative Forcing Variations Over Mega-City Delhi. Ann. Geophys. 28, 1157-1166. doi:10.5194/angeo-28-1157-2010

Stanier, C. O., Kylstov, A. Y., and Pandis, S. N. (2004). Nucleation Events during the Pittsburgh Air Quality Study: Description and Relation to Key Meteorological, Gas Phase, and Aerosol Parameters. Aerosol Sci. Tech. 38, 253-264. doi:10.1080/02786820390229570

Suneja, J., Kotnala, G., Kaur, A., Mandal, T. K., and Sharma, S. K. (2019). Long-Term Measurements of $\mathrm{SO}_{2}$ over Delhi, India. MAPAN, 1-9.

Tröstl, J., Herrmann, E., Frege, C., Bianchi, F., Molteni, U., Bukowiecki, N., et al. (2016). Contribution of New Particle Formation to the Total Aerosol Concentration at the High-altitude Site Jungfraujoch $(3580 \mathrm{M}$ Asl, Switzerland). J. Geophys. Res. Atmos. 121 (19), 11692-11711. doi:10.1002/ 2015JD024637

Ueda, S., Miura, K., Kawata, R., Furutani, H., Uematsu, M., Omori, Y., et al. (2016). Number-size Distribution of Aerosol Particles and New Particle Formation Events in Tropical and Subtropical Pacific Oceans. Atmos. Environ. 142, 324-339. doi:10.1016/j.atmosenv.2016.07.055

Valavanidis, A., Fiotakis, K., and Vlachogianni, T. (2008). Airborne Particulate Matter and Human Health: Toxicological Assessment and Importance of Size and Composition of Particles for Oxidative Damage and Carcinogenic 
Mechanisms. J. Environ. Sci. Health Part. C 26, 339-362. doi:10.1080/ 10590500802494538

Verheggen, B., and Mozurkewich, M. (2002). Determination of Nucleation and Growth Rates from Observation of a SO2 Induced Atmospheric Nucleation Event. J. Geophys. Res. 107, 4123. doi:10.1029/2001JD000683

Warner, J., and Twomey, S. (1967). The Production of Cloud Nuclei by Cane Fires and the Effect on Cloud Droplet Concentration. J. Atmos. Sci. 24, 704-706. doi:10.1175/1520-0469(1967)024<0704:TPOCNB>2.0.CO;2

Weber, R. J., Marti, J. J., McMurry, P. H., Eisele, F. L., Tanner, D. J., and Jefferson, A. (1997). Measurements of New Particle Formation and Ultrafine Particle Growth Rates at a Clean continental Site. J. Geophys. Res. Atmos. 102 (D4), 4375-4385. doi:10.1029/96JD03656

Wehner, B., Siebert, H., Ansmann, A., Ditas, F., Seifert, P., Stratmann, F., et al. (2010). Observations of Turbulence-Induced New Particle Formation in the Residual Layer. Atmos. Chem. Phys. 10, 4319-4330. doi:10.5194/acp-10-43192010

Wiedensohler, A., Birmili, W., Nowak, A., Sonntag, A., Weinhold, K., Merkel, M., et al. (2012). Mobility Particle Size Spectrometers: Harmonization of Technical Standards and Data Structure to Facilitate High Quality Long-Term Observations of Atmospheric Particle Number Size Distributions. Atmos. Meas. Tech. 5, 657-685. doi:10.5194/amt-5-657-2012

Yue, D., Hu, M., Wu, Z., Wang, Z., Guo, S., Wehner, B., et al. (2009). Characteristics of Aerosol Size Distributions and New Particle Formation in the Summer in Beijing. J. Geophys. Res. Atmos. 114 (D2), 1. doi:10.1029/2008JD010894
Zhang, Q., Jimenez, J. L., Canagaratna, M. R., Ulbrich, I. M., Ng, N. L., Worsnop, D. R., et al. (2011). Understanding Atmospheric Organic Aerosols via Factor Analysis of Aerosol Mass Spectrometry: a Review. Anal. Bioanal. Chem. 401, 3045-3067. doi:10.1007/s00216-011-5355-y

Conflict of Interest: The authors declare that the research was conducted in the absence of any commercial or financial relationships that could be construed as a potential conflict of interest.

The handling editor is currently co-organizing a Research Topic with one of the authors SS, and confirms the absence of any other collaboration.

Publisher's Note: All claims expressed in this article are solely those of the authors and do not necessarily represent those of their affiliated organizations, or those of the publisher, the editors and the reviewers. Any product that may be evaluated in this article, or claim that may be made by its manufacturer, is not guaranteed or endorsed by the publisher.

Copyright (c) 2021 Jose, Mishra, Lodhi, Sharma and Singh. This is an open-access article distributed under the terms of the Creative Commons Attribution License (CC $B Y)$. The use, distribution or reproduction in other forums is permitted, provided the original author(s) and the copyright owner(s) are credited and that the original publication in this journal is cited, in accordance with accepted academic practice. No use, distribution or reproduction is permitted which does not comply with these terms. 